\title{
Reuse of peanut shells and Azolla mixes as a peat alternative in growth medium of Dieffenbachia amoena'tropic snow'
}

\author{
Ali Mahboub Khomami ${ }^{1}$ (D) Mohammad Naghi Padasht ${ }^{2} \cdot$ Ali Ajili Lahiji $^{1}$ Fariba Mahtab $^{3}$
}

Received: 28 November 2017 / Accepted: 24 December 2018 / Published online: 10 January 2019

(c) The Author(s) 2019

\begin{abstract}
Purpose An experiment was designed to introduce a substitute for peat, which is used in the production of bedding for the cultivation of ornamental plants and is imported and expensive. For this reason, the usability of peanut shells and Azolla, whose accumulation in the environment causes environmental problems, is a major research question.

Methods In this work, Dieffenbachia amoena was grown in a growing medium that had substituted peanut shells and Azolla mixes composts $(0,15,30,45,60$, and $100 \mathrm{v} / \mathrm{v} \%)$ for peat. The controls received only peat: perlite $(2: 1 \mathrm{v} / \mathrm{v})$ without composts.

Results It was found that, as the substitution of compost increased, nutrients also increased in the growing medium. Nonetheless, the nutrients led to minor changes in the leaves. As compost increased, the bulk density of the growing media decreased $\left(0.17,0.16,0.15\right.$, and $\left.0.15 \mathrm{~g} \mathrm{~cm}^{-3}\right)$. The range of substrate physical properties, such as container capacity, airfilled porosity, and total porosity, was within the recommended range. The 15-100\% substitution of compost increased the electrical conductivity and $\mathrm{pH}$ of the growing media. The $30 \%$ compost treatment led to significant differences in the final height $(32.06 \mathrm{~cm})$, trunk diameter $(11.66 \mathrm{~mm})$, stem and leaf fresh weight $(57.52 \mathrm{~g})$, and stem and leaf dry weight $(5.10 \mathrm{~g})$ in comparison with the controls.

Conclusions Considering the high price of peat in comparison with compost, replacing peat with $30 \%$ compost is economically preferable. Compost was thus found to be a good alternative to peat as an ornamental plants growing medium.
\end{abstract}

Keywords Compost $\cdot$ Foliage plants $\cdot$ Nitrogen $\cdot$ Ornamental plants $\cdot$ Physical characteristics

\section{Introduction}

Peanut shells are a waste remaining from the cultivation of peanuts in considerable amounts. The compost of this waste can be used as an available and inexpensive material for use in the production of ornamental plants' growing media. In Iran, peanut is cultivated in an area of 3218 hectares, with 2718 hectares located in Gilan Province (Torkashvand et al.

Ali Mahboub Khomami

mahboub48@yahoo.com

1 Soil and Water Research Department, Gilan Agricultural and Natural Resources Research and Education Center, AREEO, Rasht, Iran

2 Horticulture Crops Research Department, Gilan Agricultural and Natural Resources Research and Education Center, AREEO, Rasht, Iran

3 Department of Horticulture, Faculty of Agriculture, Islamic Azad University, Rasht Branch, Rasht, Iran
2015). Aquatic fern Azolla (Azolla filiculoides) is not native to Iran and entered the northern provinces of the country in 1991 and was quickly developed in paddy fields and wetlands and created many problems for rice farmers and the environment.

Azolla performs well in terms of Azolla production and is a good natural fertilizer in ecological terms (Pabby et al. 2003). Collecting and commercializing its use, therefore, not only help solve some of the existing environmental problems, but may also have economic benefits (Khomami and Dehkaei 2010). In addition to its local production, a considerable amount of peanut is imported to the country with shell. Due to the limited and inadequate peat resources in Iran and the heavy costs of peat importation from abroad, investigating the possibility of replacing peat with new and inexpensive resources is a must. Soilless growing media are crucial to the production of potting plants. In addition to their desirable physical, chemical, and biological characteristics, suitable growing media should also be economically 
accessible, affordable, sustainable, and lightweight, so that they are easier to work with and have an effective cost of transport (Davidson et al. 1998). Rauch et al. (1997) used manure and wood chips and waste paper with a mixture of volcanic materials as a growing medium for potted Crotone, Cordyline, Chrysanthemum, and Ligustrum and concluded that these materials can be used as an organic substrate for this plant. Khomami et al. (2015) concluded that a mixture of cow manure and sawdust is appropriate for feeding earthworms and its outcome is quality vermicompost, and reported that this vermicompost provides an inexpensive, high-quality, peat-like substitute for Dieffenbachia amoena production (Khomami and Mohammadoov 2014). The study of the physical properties of compost is an important factor in evaluating the efficiency of compost in growing media. Cristiano et al. (2018) concluded that replacing peat with sewage sludge-based compost at 30 and $60 \%$ doses yields the poorest results in terms of the diameter of the plant, shoot, leaves, flowers, and fresh and dry masses, which likely decrease due to the physical composition of compost. Baran et al. (2001) used a grape waste compost instead of peat in the growing media of the houseplant Hypoestes and concluded that, as an alternative to peat, grape compost should take up 50\% of the mix. The present experiment was designed to investigate the possibility of using Azolla peanut shell compost as an alternative to peat.

\section{Materials and methods}

This study was conducted in the Flowers and Ornamental Plants Research Station in Lahijan $\left(37^{\circ} 11^{\prime} 44^{\prime \prime}\right.$ and $\left.50^{\circ} 01^{\prime} 03^{\prime \prime}\right)$. To develop a suitable growing media, peanut shells were collected from peanut-drying workshops in Astaneh, Gilan Province, and Azolla was collected from the wetlands of this province. After mixing the peanut shells and Azolla with an equal volume ratio (1:1), they were dumped in 1 -cubic-meter $(1 \times 1 \times 1)$ wooden boxes with pores for providing aerobic conditions and microbial activity (Figs. 1, 2 ). The temperature was measured in the center of the compost mass by a thermometer every 3-5 days, and the material was removed from the boxes and adjusted to create a good ventilation, and the moisture content of the mass was adjusted; this operation continued for 4 months until the temperature stability and maturity of the compost mass was sustained.

Considering the importance of this ornamental foliage plant in the manufacturing of ornamental plants in Iran and its role as an experimental plant, D. amoena was selected for this experiment. Rooted cuttings of the plants were prepared in almost equal sizes. After transferring the plants to pots containing growing media (with a diameter of $10 \mathrm{~cm}$ ), the plant was grown over 5 months in a fiberglass covered

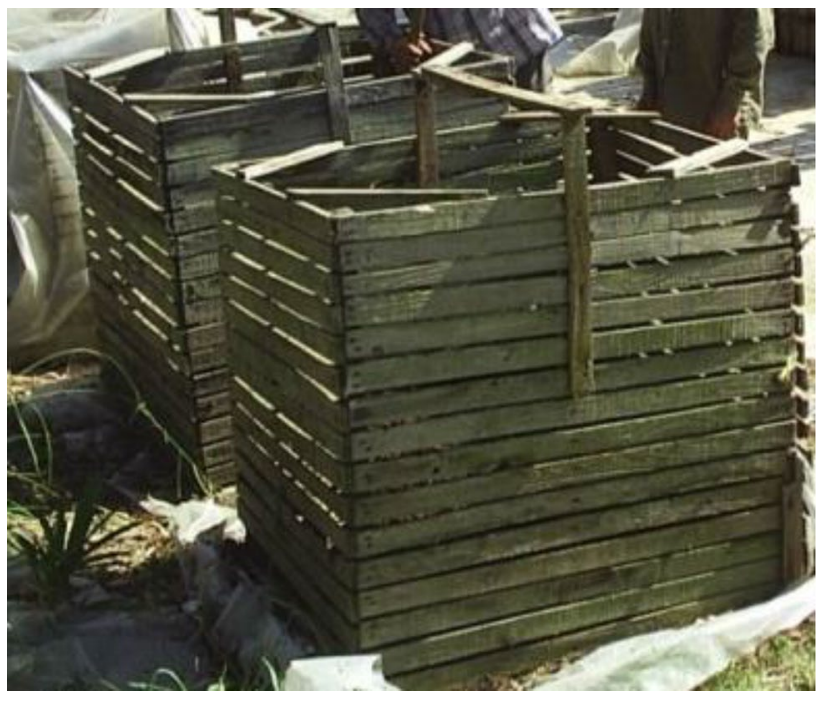

Fig. 1 Used wooden box to produce peanut shell + Azolla compost

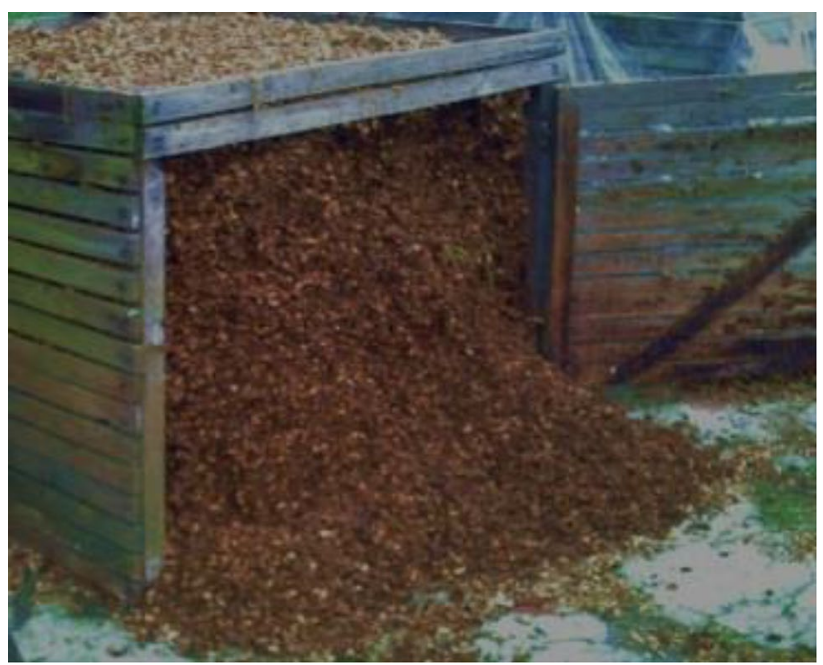

Fig. 2 Provided peanut shells + Azolla compost

greenhouse at the Ornamental Plant Research Station of Lahijan, Iran. The average night and daily temperatures were $18 \pm 2$ and $27 \pm 2{ }^{\circ} \mathrm{C}$, respectively, and the relative humidity was $65-75 \%$ and the average light was equal to that produced by $75-150$-foot candles. This experiment was carried out using a completely randomized design with six treatment substrates, including peat substrate and perlite (2:1) and five substrate compositions with $15,30,45,60$, and $100 \%$ of peanut shells + Azolla compost, which have replaced peat (Table 1), with three replications and four plants per treatment. To enable the plants' adaptation to the new conditions, they were watered right in the pot a week before giving them the nutrient solution. For each pot, $200 \mathrm{ml}$ of Omex fertilizer containing $18 \%$ nitrogen, $18 \%$ phosphorus and $18 \%$ 
Table 1 Composition of the growing media

\begin{tabular}{ll}
\hline $\begin{array}{l}\text { Percent of } \\
\text { compost } \\
(\%)\end{array}$ & Combination \\
\hline 0 & 2 peat +1 perlite $($ control $)$ \\
15 & 1.7 peat +1 perlite +0.3 peanut shells + Azolla compost \\
30 & 1.4 peat +1 perlite +0.6 peanut shells + Azolla compost \\
45 & 1.1 peat +1 perlite +0.9 peanut shells + Azolla compost \\
60 & 0.8 peat +1 perlite +1.2 peanut shells + Azolla compost \\
100 & 0 peat +1 perlite +2 peanut shells + Azolla compost \\
\hline
\end{tabular}

potassium was added every 7 days. At the end of the growing season, plant-growing factors such as height, diameter, stem and leaf fresh weight and stem and leaf dry weight were measured. To measure the dry weight, the stem and leaf samples were dried for $48 \mathrm{~h}$ at $75^{\circ} \mathrm{C}$ in an oven (Khomami and Mohammadoov 2014).

The total nitrogen was determined by the procedure proposed by Bremner and Mulvaney (1982) after digesting the samples with concentrated $\mathrm{H}_{2} \mathrm{SO}_{4}$ and $\mathrm{HC}_{1} \mathrm{O}_{4}(9: 1 \mathrm{v} / \mathrm{v})$. Each ground sample was ashed in a muffle furnace at $550{ }^{\circ} \mathrm{C}$ to determine the other nutrients (Horwitz 1980).

Total P was analyzed according to Murphy and Riley (1962) by a spectrophotometer (CECIL 2041). According to Houba et al. (1989), the total K was analyzed by a flame photometer (JENWAY PFP7). The total organic carbon was measured according to the method proposed by Nelson and Sommers (1982). According to the method proposed by Munter and Grande (1981), Ca, $\mathrm{Mg}, \mathrm{Fe}, \mathrm{Cu}$, and $\mathrm{Zn}$ were determined in the plants and substrate samples by inductively coupled plasma atomic emission spectroscopy. Physical properties such as total porosity, bulk density, air-filled porosity, and container capacity were measured using Fonteno's (1996) method and EC and pH were measured using the method proposed by Verdonck and Gabriels (1992). The data were analyzed in the SAS software (SAS Institute Inc 2001) and the means of the data were statistically compared using Tukey's multiple-range test.

\section{Results and discussion}

The physicochemical characteristics of growing media have a great impact on plant quality. The results in Table 2 show that, due to the high $\mathrm{C} / \mathrm{N}$ ratio of peanut shells and the low ratio of Azolla, their composition has a balanced ratio of $\mathrm{C} / \mathrm{N}$ and improved compost quality compared to raw materials.

The results in Table 3 show that increasing the amount of peanut shells + Azolla compost led to an increased nitrogen, phosphorus, and potassium in the growing medium compared to the controls, and the highest content was reached with $100 \%$ peanut shells + Azolla compost. These findings are consistent with the results obtained by Khomami and Moharam (2013), who reported an increase
Table 2 Some physicochemical properties of peanut shells + Azolla compost, peanut shells, Azolla, and peat

\begin{tabular}{lllll}
\hline Physicochemical properties & $\begin{array}{l}\text { Peanut shells + Azolla } \\
\text { compost }\end{array}$ & Peanut shells & Azolla & Peat \\
\hline Total nitrogen (\%) & 2.9 & 0.87 & 2.8 & 0.63 \\
Available phosphorus $\left(\mathrm{mg} \mathrm{kg}^{-1}\right)$ & 4000 & 1190 & 5100 & 300 \\
Available potassium $\left(\mathrm{mg} \mathrm{kg}^{-1}\right)$ & 19,300 & 18,700 & 23,800 & 3100 \\
Organic carbon (\%) & 21.8 & 30 & 38.8 & 21.2 \\
C/N ratio & 4.1 & 34.5 & 13.9 & 10.1 \\
PH (1:5) & 6.03 & 5.89 & 7.4 & 5.52 \\
EC (dS m-1) & 2.5 & 1.38 & 5.47 & 0.62 \\
\hline
\end{tabular}

Table 3 Some chemical properties of growth media

\begin{tabular}{llllll}
\hline Treatment & $\begin{array}{l}\text { Total } \\
\text { nitrogen } \\
(\%)\end{array}$ & $\begin{array}{l}\text { Available } \\
\text { phosphorus } \\
\left(\mathrm{mg} \mathrm{kg}^{-1}\right)\end{array}$ & $\begin{array}{l}\text { Avail- } \\
\text { able potassium } \\
\left(\mathrm{mg} \mathrm{kg}^{-1}\right)\end{array}$ & $\begin{array}{l}\text { Organic } \\
\text { carbon } \\
(\%)\end{array}$ & C/N ratio \\
\hline Control & $0.6 \mathrm{f}$ & $300 \mathrm{f}$ & $3100 \mathrm{f}$ & $37.8 \mathrm{a}$ & $63.0 \mathrm{a}$ \\
15\% peanut shells + Azolla compost & $1.9 \mathrm{e}$ & $1900 \mathrm{e}$ & $14,400 \mathrm{e}$ & $29.2 \mathrm{~b}$ & $15.3 \mathrm{~b}$ \\
30\% peanut shells + Azolla compost & $2.0 \mathrm{~d}$ & $3100 \mathrm{~d}$ & $14,800 \mathrm{~d}$ & $28.5 \mathrm{~b}$ & $14.2 \mathrm{~b}$ \\
45\% peanut shells + Azolla compost & $2.3 \mathrm{c}$ & $4300 \mathrm{c}$ & $17,700 \mathrm{c}$ & $24.3 \mathrm{bc}$ & $10.5 \mathrm{c}$ \\
60\% peanut shells + Azolla compost & $2.4 \mathrm{~b}$ & $4600 \mathrm{~b}$ & $19,000 \mathrm{~b}$ & $24.3 \mathrm{bc}$ & $10.1 \mathrm{c}$ \\
$100 \%$ peanut shells + Azolla compost & $2.8 \mathrm{a}$ & $4900 \mathrm{a}$ & $19,900 \mathrm{a}$ & $22.1 \mathrm{c}$ & $7.6 \mathrm{c}$ \\
\hline
\end{tabular}

The means of the same letters do not significantly differ $(p \leq 0.05)$ 
in the amount of nitrogen, phosphorus, and potassium by an increase in sugarcane bagasse vermicompost in the growing medium. The highest nitrogen content was reached with $100 \%$ peanut shells + Azolla and the lowest nitrogen content belonged to the controls. The amount of phosphorus also increased with an increase in the replacement rate of peanut shells + Azolla compost, and the highest amount of potassium $\left(19,900 \mathrm{mg} \mathrm{kg}^{-1}\right)$ was reached with $100 \%$ peanut shells + Azolla and the lowest potassium content $\left(3100 \mathrm{mg} \mathrm{kg}^{-1}\right)$ belonged to the controls. The results showed that, in comparison with peat, a significant amount of potassium was present in peanut shells + Azolla compost, which is consistent with the results reported by Grigatti et al. (2007). Due to the high amounts of potassium in peanut shells + Azolla compost (Table 4), its addition to growing media led to an increase in the available amount of potassium. Due to the low nitrogen content in the controls, the $\mathrm{C} / \mathrm{N}$ ratio was also shown to be higher. The $\mathrm{C} / \mathrm{N}$ ratio reduced as the compost surface increased in the growing media, which is consistent with the results obtained by Jayasinghe et al. (2010). The $\mathrm{C} / \mathrm{N}$ ratio was lower than the permitted standard for the growing of ornamental plants $(\mathrm{C} / \mathrm{N}=30)$ in the growing media containing peanut shells + Azolla compost. Davidson et al. (1994) reported that compost with a $\mathrm{C} / \mathrm{N}$ ratio less than 20 is ideal for plant production. The highest $\mathrm{pH}$ and $\mathrm{EC}$ values were reached with the $100 \%$ peanut shells + Azolla compost substrate and the lowest pertained to the controls.

\section{Plant nutrient analysis}

The leaf analysis of the plants (Table 4) grown in potting mixtures containing $30 \%$ peanut shells + Azolla compost showed a significant increase in the nitrogen concentration compared to the controls, which could explain the increase in the growth of the plants after replacing peat with $30 \%$ peanut shells + Azolla compost (Table 3). The elemental composition of the leaves for other elements shows slight differences in nutrient concentrations between the treatments (Table 4).

The average nutrient content obtained is in line with the values given by Uchida (2010) for good-quality plants. The differences in plant growth between the treatments appear to not have been a direct result of excessive or deficient nutrients. The fact that the plants were fertilized every 10 days with a nutrient solution supports this interpretation. In substrates, where peanut shells + Azolla compost has replaced peat, other factors seem to have also affected plant growth in addition to the nutritional value of compost, and these factors need to be further investigated.

\section{Plant growth factors}

The mean comparisons shown in Table 5 suggest that the highest final height of the plant $(32.66 \mathrm{~cm})$ pertained to $30 \%$ peanut shells + Azolla compost, which had a significant difference with $100 \%$ peanut shells + Azolla compost.
Table 4 Nutrient element concentration analyses of Dieffenbachia amoena leaves

\begin{tabular}{lllllllll}
\hline Treatment & $\begin{array}{l}\mathrm{N} \\
(\%)\end{array}$ & $\begin{array}{l}\mathrm{P} \\
(\%)\end{array}$ & $\begin{array}{l}\mathrm{K} \\
(\%)\end{array}$ & $\begin{array}{l}\mathrm{Ca} \\
(\%)\end{array}$ & $\begin{array}{l}\mathrm{Mg} \\
(\%)\end{array}$ & $\begin{array}{l}\mathrm{Cu} \\
(\mathrm{ppm})\end{array}$ & $\begin{array}{l}\mathrm{Zn} \\
(\mathrm{ppm})\end{array}$ & $\begin{array}{l}\mathrm{Fe} \\
(\mathrm{ppm})\end{array}$ \\
\hline Control & $2.14 \mathrm{ac}$ & 0.69 & $4.16 \mathrm{~b}$ & 1.58 & 0.80 & 12 & 61 & $184 \mathrm{ab}$ \\
15\% peanut shells + Azolla compost & $2.43 \mathrm{ac}$ & 0.71 & $5.23 \mathrm{ab}$ & 1.10 & 0.88 & 12 & 67 & $215 \mathrm{a}$ \\
30\% peanut shells + Azolla compost & $2.70 \mathrm{a}$ & 0.79 & $5.08 \mathrm{ab}$ & 1.10 & 1.00 & 10 & 67 & $225 \mathrm{a}$ \\
45\% peanut shells + Azolla compost & $2.24 \mathrm{ac}$ & 0.76 & $5.73 \mathrm{a}$ & 0.96 & 0.86 & 12 & 61 & $201 \mathrm{ab}$ \\
60\% peanut shells + Azolla compost & $2.39 \mathrm{ac}$ & 0.75 & $5.83 \mathrm{a}$ & 1.22 & 0.91 & 12 & 58 & $205 \mathrm{ab}$ \\
$100 \%$ peanut shells + Azolla compost & $2.08 \mathrm{bc}$ & 0.72 & $4.84 \mathrm{ab}$ & 1.23 & 0.90 & 13 & 59 & $194 \mathrm{ab}$ \\
\hline
\end{tabular}

The means of the same letters do not significantly differ $(p \leq 0.05)$

\begin{tabular}{lllll}
\hline Treatment & Final height $(\mathrm{cm})$ & $\begin{array}{l}\text { Trunk } \\
\text { diameter } \\
(\mathrm{mm})\end{array}$ & $\begin{array}{l}\text { Stems and leaves } \\
\text { fresh weight }(\mathrm{g})\end{array}$ & $\begin{array}{l}\text { Stems and } \\
\text { leaves dry } \\
\text { weight }(\mathrm{g})\end{array}$ \\
\hline Control & $28.58 \mathrm{ab}$ & $8.34 \mathrm{ab}$ & $43.70 \mathrm{c}$ & $3.42 \mathrm{~cd}$ \\
15\% peanut shells + Azolla compost & $29.83 \mathrm{ab}$ & $7.88 \mathrm{~b}$ & $54.67 \mathrm{~b}$ & $3.67 \mathrm{c}$ \\
30\% peanut shells + Azolla compost & $32.06 \mathrm{a}$ & $11.66 \mathrm{a}$ & $57.52 \mathrm{a}$ & $5.10 \mathrm{a}$ \\
45\% peanut shells + Azolla compost & $28.83 \mathrm{ab}$ & $8.74 \mathrm{ab}$ & $50.64 \mathrm{ab}$ & $4.33 \mathrm{~b}$ \\
60\% peanut shells + Azolla compost & $28.22 \mathrm{ab}$ & $9.66 \mathrm{ab}$ & $50.24 \mathrm{ab}$ & $4.27 \mathrm{~b}$ \\
$100 \%$ peanut shells + Azolla compost & $25.95 \mathrm{bc}$ & $7.65 \mathrm{~b}$ & $43.17 \mathrm{c}$ & $3.77 \mathrm{c}$ \\
\hline
\end{tabular}

The means of the same letters do not significantly differ $(p \leq 0.05)$ 
The lowest final height of the plant $(25.95 \mathrm{~cm})$ was reached with $100 \%$ peanut shells + Azolla compost, which did not show any significant differences with the controls. The highest trunk diameter $(11.66 \mathrm{~mm})$ pertained to $30 \%$ peanut shells + Azolla compost, which differed significantly from the $15 \%$ and $100 \%$ peanut shells + Azolla compost.

The lowest diameter $(7.65 \mathrm{~mm})$ was observed in the $100 \%$ compost treatment, which showed only a significant difference with $30 \%$ peanut shells + Azolla compost. The highest stem and leaf fresh weight $(55.7 \mathrm{~g})$ was associated with $30 \%$ peanut shells + Azolla compost, which did not show significant differences with the $45 \%$ and $60 \%$ peanut shells + Azolla composts, but was significantly different from the other treatments. The lowest stem and leaf fresh weight was $43.17 \mathrm{~g}$ and was associated with the $100 \%$ peanut shells + Azolla compost, which did not show a significant difference with the controls. The highest stem and leaf dry weight $(10.5 \mathrm{~g})$ was associated with $30 \%$ peanut shells + Azolla compost, and showed a significant difference with the other treatments. The least amount of leaf dry weight $(3.42 \mathrm{~g})$ was observed in the controls, which was not significantly different with the $15 \%$ and $100 \%$ peanut shells + Azolla composts.

\section{Physical characteristics}

The study of the physical properties of growing media showed that an increase in the amount of peanut shells + Azolla compost in growing media reduced the bulk density compared to in the controls (Table 6). According to Yeager et al. (2007), the ideal bulk density of a growing medium is $0.1-0.7 \mathrm{~g} \mathrm{~cm}^{-1}$. The bulk density in compostcontaining growing media is thus ideal. The porosity of the substrates increased as the peanut shells + Azolla content increased in the growing media. As peat was replaced with peanut shells + Azolla, the bulk density of the substrates decreased, resulting in a gradual increase in the total porosity and a change in porosity distribution in the substrates.
The result was a reduced air-filled porosity and an increased container capacity (Table 6).

Taylor and Ratliff (1969) argued that the number of large pores in the growing medium and the root strength for deformation, replacement in the growing medium and longitudinal growth decreased with an increased bulk density. Increasing the amount of peanut shells + Azolla compost in the growing media increased porosity more than in the controls. Air and water contents are very crucial physical parameters of growing media (Marfà et al. 1998). Water should be available in the substrate with minimum energy levels, but at the same time, there should be sufficient air in the root zone (Inbar et al. 1993; De Boodt et al. 1974). Verdonck and Gabriels (1992) declared the ideal air-filled porosity as $20-30 \%$ of the plant growth in a growing medium. In this experiment, the percentage of air-filled porosity in the growing medium containing $15 \%$ compost was slightly more than the ideal, while it was ideal in the other substrates. Yeager et al. (2007) argued that the ideal total porosity is $50-80 \%$ in growing media. The total porosity of the substrate containing $15 \%, 30 \%$, and $45 \%$ compost is within this ideal range. A high total porosity was found in $100 \%$ peanut shells + Azolla and the lowest in 15\% and 30\% compost. As estimated by Verdonck and Gabriels (1992), the ideal container capacity for growing media is between 55 and $75 \%$; it thus seems that the container capacity is less than optimal in all growing media. In this experiment, the highest container capacity was observed in the control medium and the lowest in the growing media containing $15 \%$ peanut shells + Azolla compost. By increasing the amount of peanut shells + Azolla compost in the growing media, air-filled porosity decreased. The highest air-filled porosity was observed in the growing medium of $15 \%$ compost and the lowest in the growing medium of $100 \%$ compost. With the increase in the peanut shells + Azolla compost content in the growing media, $\mathrm{pH}$ and EC increased. Grigatti et al. (2007) reported an increase in $\mathrm{pH}$ and $\mathrm{EC}$ in plant-growing media after increasing the amount of green waste compost to $25 \%, 50 \%, 75 \%$, and

Table 6 Physical characteristics of substrates

\begin{tabular}{|c|c|c|c|c|c|c|}
\hline Treatment & $\begin{array}{l}\text { Bulk density } \\
\left(\mathrm{g} \mathrm{cm}^{-3}\right)\end{array}$ & $\begin{array}{l}\text { Total porosity } \\
(\%)\end{array}$ & $\begin{array}{l}\text { Air-filled porosity } \\
(\%)\end{array}$ & $\begin{array}{l}\text { Container capacity } \\
(\%)\end{array}$ & $\mathrm{pH}(1: 5)$ & $\mathrm{EC}(\mathrm{dS} \mathrm{m}-1)$ \\
\hline Control & $0.23 \mathrm{a}$ & $73.60 \mathrm{c}$ & $24.20 \mathrm{c}$ & $52.30 \mathrm{a}$ & $5.55 b c$ & $0.67 \mathrm{e}$ \\
\hline $15 \%$ peanut shells + Azolla compost & $0.17 \mathrm{~b}$ & $65.53 \mathrm{e}$ & $30.47 \mathrm{a}$ & $37.79 \mathrm{~d}$ & $5.67 \mathrm{~b}$ & $1.06 \mathrm{~d}$ \\
\hline $30 \%$ peanut shells + Azolla compost & $0.16 b$ & $67.44 d$ & $28.56 b$ & $38.37 \mathrm{~d}$ & $5.27 \mathrm{c}$ & $1.70 \mathrm{c}$ \\
\hline $45 \%$ peanut shells + Azolla compost & $0.15 b$ & $72.67 \mathrm{c}$ & $23.33 \mathrm{c}$ & $41.28 \mathrm{c}$ & $5.65 b$ & $1.92 \mathrm{c}$ \\
\hline $60 \%$ peanut shells + Azolla compost & $0.15 b$ & $85.47 \mathrm{~b}$ & $15.53 \mathrm{~d}$ & $41.86 \mathrm{cb}$ & $5.80 \mathrm{~b}$ & $2.10 \mathrm{~b}$ \\
\hline \multirow[t]{2}{*}{$100 \%$ peanut shells + Azolla compost } & $0.15 b$ & $89.53 a$ & $10.47 \mathrm{e}$ & $43.02 \mathrm{~b}$ & $6.05 a$ & $2.60 \mathrm{a}$ \\
\hline & $0.19-0.70^{\mathrm{a}}$ & $50-85^{\mathrm{a}}$ & $10-30^{\mathrm{a}}$ & $45-65^{\mathrm{a}}$ & $5.5-6.5^{\mathrm{b}}$ & $0.76-1.25^{\mathrm{b}}$ \\
\hline
\end{tabular}

${ }^{\text {a }}$ Rang values are recommended physical characteristics (Yeager et al. 2007)

${ }^{\mathrm{b}}$ Cavins et al. (2000) 
$100 \%$ volumes for peat substitution. The highest EC content $\left(2.6 \mathrm{dS} \mathrm{m}^{-1}\right)$ was observed in the medium containing $100 \%$ peanut shells + Azolla compost and the lowest EC (0.62 dS $\mathrm{m}-1$ ) in the controls. Cavins et al. (2000) proposed the ideal $\mathrm{pH}$ as $5.5-6.5$ and EC as $0.76-1.25 \mathrm{dS} \mathrm{m}-1$ for optimal plant growth. Accordingly, in this experiment, $\mathrm{pH}$ was in the proper range in all the compost replacement treatments. At levels higher than $30 \%$ peanut shells + Azolla compost, the EC was higher and fell out of this range. In general, the combination of compost and peat in plant-growing media increases the $\mathrm{pH}$ (Bustamante et al. 2008). The highest $\mathrm{pH}$ was obtained in the treatments containing $100 \%$ peanut shells + Azolla compost and the lowest $\mathrm{pH}$ in the controls. Chen et al. (1988) considered the physical characteristics of growth media as the most important factor that affected potted plants' yield. They also reported that the best plant growth compared to the controls $(20 \%$ vermiculite $+80 \%$ peat) was in the growing medium containing $50 \%$ peat $+50 \%$ compost (including animal manure or compost grape pulp).

\section{Conclusion}

The results showed that the highest growth was observed in the treatments containing 30\% peanut shells + Azolla and the lowest growth rate in the $100 \%$ peanut shells + Azolla compost. Examining the physical properties of growing media in relation with plant growth showed that plant growth was lower with $100 \%$ peanut shells + Azolla compost than with the other growing media, and in terms of growth factors, the yielded plant was poor. Peanut shells + Azolla compost has a reduced $\mathrm{C} / \mathrm{N}$ ratio and appropriate $\mathrm{pH}, \mathrm{EC}$ and growth characteristics, such as height, trunk diameter, stem and leaf fresh weight and stem and leaf dry weight compared to the controls. The observations made in this experiment showed that peanut shells + Azolla compost can be used to substitute peat in the growing media of $D$. amoena.

Acknowledgements We appreciated from our colleagues in the Ornamental Plants Research Station of Lahijan for their help.

Funding The studied was funded by Agricultural Research Education and Extention Organization of Iran.

Open Access This article is distributed under the terms of the Creative Commons Attribution 4.0 International License (http://creativeco mmons.org/licenses/by/4.0/), which permits unrestricted use, distribution, and reproduction in any medium, provided you give appropriate credit to the original author(s) and the source, provide a link to the Creative Commons license, and indicate if changes were made.

\section{References}

Baran A, Çaycı G, Kütük C, Hartmann R (2001) Composted grape marc as growing medium for hypostases (Hypostases phyllostagya). Bioresour Technol 78:103-106. https://doi.org/10.1016/ S0960-8524(00)00171-1

Bremner JM, Mulvaney RG (1982) Nitrogen total. In: Page AL, Miller RH, Keeney DR (eds) Method of soil analysis. American Society of Agronomy, Madison, pp 575-624. https://doi.org/10.2134/ agronmonogr9.2.2ed.c31

Bustamante MA, Paredes C, Moral R, Agullo E, Perez-Murcia MD, Abad M (2008) Composts from distillery wastes as peat substitutes for transplant production. Resour Conserv Recycl 52:792799. https://doi.org/10.1016/j.resconrec.2007.11.005

Cavins TJ, Whipker BE, Fonteno WC, Harden B, McCall I, Gibson JL (2000) Monitoring and managing $\mathrm{pH}$ and EC using the PourThru extraction method. North Carolina State, Horticulture Information Leaflet 590, pp 1-17

Chen Y, Inbar Y, Hadar Y (1988) Composted agricultural wastes as potting media for ornamental plants. Soil Sci 145:298-303. https ://doi.org/10.1097/00010694-198804000-00009

Cristiano G, Vuksani G, Tufarelli V, De Lucia B (2018) Response of Weeping Lantana (Lantana montevidensis) to compost-based growing media and electrical conductivity level in soilless culture: first evidence. Plants 7(24):1-11. https://doi.org/10.3390/ plants 7010024

Davidson H, Mecklenburg R, Peterson C (1994) Nursery management: administration and culture. 3rd edn. Prentice-Hall. Inc., Englewood Cliffs (NJ), p 486

Davidson H, Mecklenburg R, Peterson C (1998) Nursery management: administration and culture. 2nd edn., Prentice-Hall, Inc., New Jersey, p 173

De Boodt M, Verdonck O, Cappaert I (1974) Method for measuring the waterrelease curve of organic substrates. Acta Hortic 37:2054 2063. https://doi.org/10.17660/ActaHortic.1974.37.20

Fonteno WC (1996) Growing media: types and physical/chemical properties. In: Reed DW (ed) Water, media, and nutrition of greenhouse crops. Ball Publications, Batavia, pp 93-122

Grigatti M, Giorgioni ME, Ciavatta C (2007) Compost-based growing media: influence on growth and nutrient use of bedding plants. Bioresour Technol 98:3526-3534. https://doi.org/10.1016/j.biort ech.2006.11.016

Horwitz W (1980) Official methods of analysis of the Association of Official Analytical Chemist, 13th edn. Assoc Off Anal Chem, Arlington

Houba VJG, Van der Lee JJ, Novozamsky I, Walinga I (1989) Soil and plant analysis, a series of syllabi, part 5 , soil analysis procedures. Wageningen Agricultural University, Wageningen

Inbar Y, Hadar Y, Chen Y (1993) Recycling of cattle manure: the composting process and characterization of maturity. J Environ Qual 22:857-863. https://doi.org/10.2134/jeq1993.004724250022000 40032x

Jayasinghe GY, Liyana Arachchi ID, Tokashiki Y (2010) Evaluation of containerized substrates developed from cattle manure compost and synthetic aggregates for ornamental plant production as a peat alternative. Resour Conserv Recycl 54:1412-1418. https:// doi.org/10.1016/j.resconrec.2010.06.002

Khomami AM, Dehkaei MNP (2010) Effect of composted Azolla in different growth media on growth and nutrient element composition in Ficus benjamina plant cv. Starlight. Seed Plant Prod J 4(25):417-430. https://doi.org/10.22092/SPPJ.2017.110387 (In Persian)

Khomami AM, Mohammadoov GM (2014) Growth of Dieffenbachia amoena 'tropic snow' in growing media containing 
sugarcane bagasse and sawdust vermicompost. J Ornamental Plant 4(2):61-67

Khomami AM, Moharam G (2013) Evaluation of sugarcane bagasse vermicompost as potting media on growth and nutrition of Dieffenbachia amoena 'tropic snow'. Int J Agron Plant Prod 4(8):1806-1812. https://www.cabdirect.org/cabdirect/mobile/ abstract/20133272647\#. Accessed 9 Jan 2018

Khomami AM, Mammadov GM, FatemiChokami A, Sedaghathoor S (2015) Growth and reproductive performance of Eisenia Foetida in cow manure, cow manure + sugarcane bagasse, and cow manure + sawdust waste. Appl Ecol Env Res 14(1):237-247. https ://doi.org/10.15666/aeer/1401_237247

Marfà O, Tort JM, Olivella C, Cáceres R, Martínez FX (1998) Cattle manure compost as substrate. ii-conditioning and formulation of growing media for cut flower cultures. Acta Hortic 469:305-312. https://doi.org/10.17660/ActaHortic.1998.469.32

Munter RC, Grande RA (1981) Plant tissue and soil extract analysis by ICP-atomic emission spectrometry. In: Barnes RM (ed) Developments in atomic plasma spectrochemical analysis. Heyden and Son Ltd., London, pp 653-672

Murphy J, Riley JP (1962) A modified single solution method for the determination of phosphate in natural waters. Anal Chim Acta 27:31-36. https://doi.org/10.1016/s0003-2670(00)88444-5

Nelson DW, Sommers LE (1982) Total carbon, organic carbon and organic matter. In: Page AL, Miller RH, Keeney DR (eds) Methods of soil analysis. Part 2 chemical and microbiological properties. ASA, SSSA Publ, Madison, pp 539-579

Pabby A, Prasanna R, Nayak S, Singh PK (2003) Physiological characterization of the cultured and freshly isolated endosymbionts from different species of Azolla. Plant Physiol Biochem 41:73-79. https ://doi.org/10.1016/S0981-9428(02)00011-6

Rauch FD, Gitlin HM, Watanabe R, Stanley RW (1997) Plant growth in potting media using compost. University of Hawaii, Honolulu
(HI). 4 p. (Horticultural Research Note; HRN-10). https://schol arspace.manoa.hawaii.edu/handle/10125/12271. Accessed 9 Jan 2018

SAS Institute Inc (2001) SAS procedures guide, version 8.2. SAS Institute Inc, Cary

Taylor HM, Ratliff LF (1969) Root elongation rates of cotton and peanuts as a function of soil strength and soil water content. Soil Sci 108:113-119. https://doi.org/10.1097/00010694-19690 8000-00006

Torkashvand AM, Alidoust M, Khomami AM (2015) The reuse of peanut organic wastes as a growth medium for ornamental plants. Int J Recycl Org Waste Agriculture 4(2):85-94. https://doi. org/10.1007/s40093-015-0088-0

Uchida R (2010) Recommended plant tissue nutrient levels for some vegetable, fruit, and ornamental foliage and flowering plants in Hawai'i. In: Silva JA, Uchida R (eds) Plant Nutrient Management in Hawai'i's Soils, Approaches for Tropical and Subtropical Agriculture. CTAHR: Honolulu, HI, USA, pp 57-65

Verdonck DO, Gabriels R (1992) International society for horticultural science. Acta Hortic 302:169-180. https://doi.org/10.17660 /ActaHortic.1992.302.16

Yeager TH, Bilderback TE, Fare D, Gilliam C, Lea-Cox JD, Niemiera AX, Ruter JM, Tilt K, Warren S, Whitwell T, Wright RD (2007) Best management practices: Guide for producing nursery crops, 2nd edn. S. Nursery Assoc, Atlanta

Publisher's Note Springer Nature remains neutral with regard to jurisdictional claims in published maps and institutional affiliations. 